\title{
Using Social Media Marketing to Create Brand Awareness, Brand Image, and Brand Loyalty on Tourism Sector in Indonesia
}

\author{
Santi Rimadias ${ }^{1 *}$; Nesta Alvionita ${ }^{2}$; Adinda Putri Amelia ${ }^{3}$ \\ 1,2,3 Management Study Program, Faculty of Economics, Indonesia Banking School \\ Jl Kemang Raya No. 35 Jakarta Selatan 12730, Indonesia \\ ${ }^{1}$ santi.rimadias@ibs.ac.id
}

Received: $23^{\text {rd }}$ July 2021/ Revised: $30^{\text {th }}$ July 2021/ Accepted: $02^{\text {nd }}$ September 2021

\begin{abstract}
How to Cite: Rimadias, S., Alvionita, N., \& Amelia, A. P. (2021). Using social media marketing to create brand awareness, brand image, and brand loyalty on tourism sector in Indonesia. The Winners, 22(2), 173-182.

https://doi.org/10.21512/tw.v22i2.7597
\end{abstract}

\begin{abstract}
The research aimed to examine factors that formed brand awareness and brand image of the tourism sector in Indonesia by using social media marketing on TikTok platform. The research applied a quantitative method to do a survey of 220 respondents who were users of the TikTok application. Data collection was carried out from April to May 2021, and processed by using Structural Equation Model Partial Least Square (SEM PLS). Convenience sampling was used in the research. The results show that entertainment, electronic word of mouth, and interaction positively affect consumer brand engagement. Trendiness and customization do not affect consumer brand engagement. Furthermore, it is found that consumer brand engagement positively affects brand loyalty, brand awareness, and brand image. The implication of the research is a reference for managers and policymakers in formulating strategies to improve the tourism sector in Indonesia using the model Social Media Marketing on TikTok.
\end{abstract}

Keywords: social media marketing, consumer brand engagement, brand loyalty, brand awareness, brand image

\section{INTRODUCTION}

Social media allows consumer behavior do a thorough activity ranging from visualizing consumer behavior after purchase without purchase and sharing information, ideas, and attitudes to make consumers aware of the existence of social media (Putra \& Mudiantono, 2014).

The tourism sector is one of the sectors affected by COVID-19. Data from Jakarta Statistics
Agency (Badan Pusat Statistik/BPS data record a very significant decrease in the number of tourists, both local and foreign tourists ("Perkembangan pariwisata", 2020). When compared to 2019 , the total number of tourists decreased by 75,03\% (UNWTO, 2021). The decline in tourism needs to get attention so that foreign tourists and domestic tourists can increase and become foreign exchange income of the country. Therefore, a business must have ideas and innovations to conduct studies to attract the attention of consumers, be reminded of their thoughts, create a brand image, and increase positive brand loyalty by doing all the communication channels they have in brand communication to create brand value or to protect brand value (Bilgin, 2018).

TikTok is the second most downloaded Android application worldwide. As a result of the design of the technology, and the cultural conditions surrounding it, TikTok has become the most downloaded video application, with teenagers aged 13-18 being half of the 500 million monthly users. It strategically targets user segments which video hosting websites and editing applications have not considered in the past. Children born in the 2010s will have fun playing with videos (Bresnick, 2019). With most people staying at home, TikTok has enjoyed phenomenal growth during the COVID-19 pandemic. It reached 12 million US users in March 2020 and a total of 52,2 million users globally. The time spent on the application and website is also increasing. For example, US visitors spent an average of 8 hours on the application during March, 10,8\% higher than the time spent in January 2020 (Su et al., 2020).

Social media marketing is a marketing process done indirectly or directly to build memory, awareness, recognition, and action for businesses, products, 
people, brands, or other entities, whose activities are using social websites such as social networking, social bookmarking, microblogging, blogging, and content sharing. Social media marketing can be explained by the approach of entertainment, interaction, trendiness, customisation, and electronic word of mouth (eWOM) (Mileva \& Fauzi DH, 2018).

Entertainment is the ability of an advertisement to fulfill the viewer's desire for entertainment, aesthetic pleasure, and emotional release (Genadi \& Furkan, 2020). Through entertainment, brands can built and strengthen a sense of closeness of consumers to persuade them in buying (Dessart, Veloutsou, \& Morgan-Thomas, 2015).

Interaction is the extent to which social media platforms offer an opportunity to get information both ways. Posting information that matches their target social media users can encourages discussion and improves relationships between consumers and brands (Cheung, Pires, \& Rosenberger, 2020).

Trendiness refers to social media providing the latest news, and hot discussion topics is also a core product search channel. Consumers will feel the motivation to get trending information about a brand within social media platforms, which encourages them to keep up with the latest developments about brands by seeking knowledge of relevant trends (Gallaugher \& Ransbotham, 2010). Trendy information can help consumers attract attention, evoke positive consumer feelings, and drive loyalty intentions (Liu, Shin, \& Burns, 2021).

Customisation is a marketing and messaging service to make consumers personally feel satisfied, making the service customizable and easy to find information to create value for certain consumers (Cheung et al., 2020).

Electronic word of mouth (eWOM) aims for communications made by prospective users or who have used brands, products using social media. EWOM will see the extent to which consumers disseminate and upload information on social media platforms. This is done to convey information about the brand by uploading content to their blog and sharing opinions with others (Cheung et al., 2020).

Consumer brand engagement allows the relationship between customers and companies to be stronger and more meaningful (Khan, Rahman, \& Fatma, 2016). The desire to better understand customer interconnectedness with brands as the object of engagement is most typical in research (Khan et al., 2016). From a multi-dimensional perspective of customer engagement, brand-customer engagement has been discussed as a multi-dimensional construction. By definition, special brand engagement includes dimensions cognitive processing, affection, and behavioral (Khan et al., 2016).

Social media marketing, which consists of entertainment, interaction, trendiness, customisation, and eWOM influence consumer brand engagement (Mileva \& Fauzi DH, 2018). Therefore, hypotheses proposed in the research and displayed in Figure 1 are:

$\mathrm{H}_{1}$ : Entertainment (ENT) positively affects consumer brand engagement (CBE).

$\mathrm{H}_{2}$ : Interaction (INT) positively affects consumer brand engagement (CBE).

$\mathrm{H}_{3}$ : Trendiness (TNS) positively affects consumer brand engagement (CBE).

$\mathrm{H}_{4}$ : Customisation (CTN) positively affects consumer brand engagement (CBE).

$\mathrm{H}_{5}$ : EWOM positively affects consumer brand engagement (CBE).

The research seeks to answer the future research submitted by previous research. The limitations of previous research focus only on one country, Hong Kong, and users of technology products (Cheung et al., 2020).

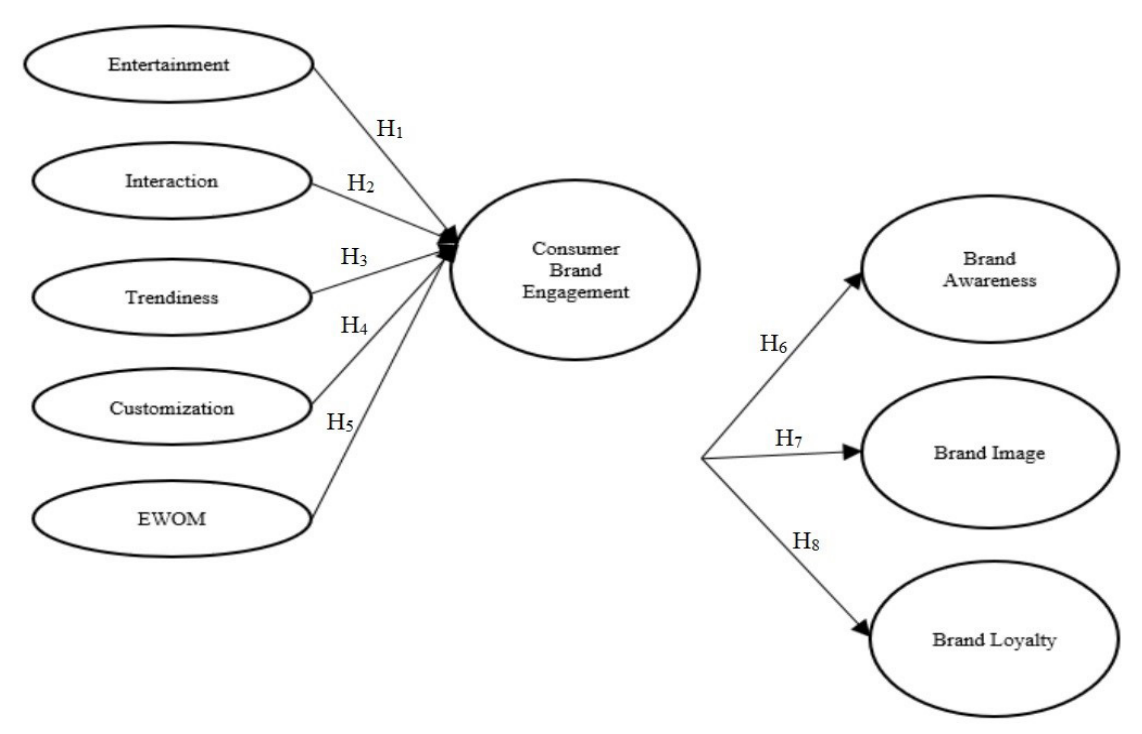

Figure 1 Research Model

Source: Author (2021) 
The research focuses on the role of social media marketing with the use of the TikTok platform. Previous research has used the social media marketing model to analyze the behavior of social media users in perceiving smartphones conducted by Cheung et al. (2020). The research answers the future research proposed by previous research to target other countries with diverse cultures and different products. Therefore, the research seeks to adopt the social media marketing model with TikTok application as the research object to analyze the forming factors of brand awareness and brand image of the tourism sector in Indonesia. The research used a modification of the research model by adding one variable, brand loyalty, adapted from the results by Fernandes and Moreira (2019).

\section{METHODS}

The research applies a quantitative approach to understand the characteristics of the population using sample data and methods of SEM PLS by using hypothesis testing on the influence between variables. Data are collected by conducting a survey techniques, namely questionnaires to respondents through questions about the use of TikTok applications that are systematically compiled based on several previous studies. Technically the data are collected through an online survey using Google Form that is distributed to respondents who are TikTok social media users over the age of 15 years.

The sampling technique used is convenience sampling. Through the efforts to disseminate data which are carried out then continued by using the formula Hair with calculation of the entire indicator multiplied by $5(44 \times 5)$ so that it gets the number of 220 TikTok user respondents (Hair, 2017). Each research variable is measured through four indicators adopted from several relevant previous studies. As shown in Table 1, the measuring instruments for entertainment, interaction, trendiness, eWOM, and customisation each amount to four indicators. Brand awareness, brand image, and brand loyalty each amount to four indicators. Consumer brand engagement consisting of cognitive processing, affection, and behavioral each amounted to four indicators. The research uses Likert scale 1-7.

Outer model analysis is to provide specifications between latent variables and manifest variables, or in other words how each indicator relates to latent variables (Nasution et al., 2020).

Inner models (structural models) are used in assessing the relationship of exogenous and endogenous latent variables concerning the calculated variance (Rahman et al., 2013). This determines the strength of the model descriptor by evaluating several quadratic double correlations (R2) and path coefficient values ( $\beta$ ) (Rahman et al., 2013).

Convergent validity is a measure of internal consistency. It is estimated to ensure that the item is assumed to measure each latent variable measuring it and not to measure other latent variables. Individual validity, Cronbach's alpha, composite reliability (CR), and average variance extracted (AVE) are suggested (Rahman et al., 2013). The convergence of the construct can be determined by calculating the reliability of the item.

Discriminant validity shows the extent to which a construct differs from another. This is examined by comparing AVE construction that is shared on itself and other constructions. For a valid construct discriminant, the AVE shared on itself must be higher than the variant shared with another construct (Rahman et al., 2013).

Reliability is the quality criteria of a construction. This requires a high degree of correlation among indicators of reliability construct extending to which a variable or set of variables is consistent with what is intended to be measured. The internal reliability of a construct is said to be achieved when the value of Cronbach's alpha is 0,7 or higher (Janadari et al., 2018).

Table 1 Operationalization of Variables

\begin{tabular}{|c|c|c|}
\hline Variable & Items & Source \\
\hline \multirow[t]{4}{*}{ Entertainment } & $\begin{array}{l}\text { [ENT1] The content found on TikTok's social media seems } \\
\text { interesting }\end{array}$ & Cheung et al. (2020) \\
\hline & [ENT2] Great fun using TikTok social media & Cheung et al. (2020) \\
\hline & $\begin{array}{l}\text { [ENT3] Collecting information about products through social } \\
\text { media TikTok is fun }\end{array}$ & Cheung et al. (2020) \\
\hline & [ENT4] It's easy to spend time using TikTok social media & Cheung et al. (2020) \\
\hline \multirow[t]{4}{*}{ Interaction } & [INT1] Easy to express my opinion through TikTok social media & Cheung et al. (2020) \\
\hline & $\begin{array}{l}\text { [INT2] Easy to express my opinion or conversation with other } \\
\text { users via TikTok social media }\end{array}$ & Cheung et al. (2020) \\
\hline & $\begin{array}{l}\text { [INT3] It is possible to have two-way interactions through } \\
\text { TikTok social media }\end{array}$ & Cheung et al. (2020) \\
\hline & $\begin{array}{l}\text { [INT4] You can share information with other users through } \\
\text { TikTok social media }\end{array}$ & Cheung et al. (2020) \\
\hline
\end{tabular}


Table 1 Operationalization of Variables (Continued)

\begin{tabular}{|c|c|c|}
\hline Variable & Items & Source \\
\hline \multirow[t]{4}{*}{ Trendiness } & $\begin{array}{l}\text { [TNS1] The content found on TikTok social media is the latest } \\
\text { content }\end{array}$ & Cheung et al. (2020) \\
\hline & [TNS2] Using social media TikTok is very trendy & Cheung et al. (2020) \\
\hline & [TNS3] TikTok's social media content is up to date & Cheung et al. (2020) \\
\hline & [TNS4] TikTok's social media use is quite fashionable & Seo and Park (2018) \\
\hline \multirow[t]{4}{*}{ Customisation } & $\begin{array}{l}\text { [CTN1] You can browse customized information on TikTok } \\
\text { social media }\end{array}$ & Cheung et al. (2020) \\
\hline & [CTN2] TikTok social media provides customized services & Cheung et al. (2020) \\
\hline & $\begin{array}{l}\text { [CTN3] TikTok social media provides interesting feed } \\
\text { information that I'm interested in }\end{array}$ & Cheung et al. (2020) \\
\hline & $\begin{array}{l}\text { [CTN4] TikTok social media can be used anytime, anywhere } \\
\text { interactions will come in. }\end{array}$ & Cheung et al. (2020) \\
\hline \multirow[t]{4}{*}{$\begin{array}{l}\text { Electronic Word of } \\
\text { Mouth }\end{array}$} & $\begin{array}{l}\text { [EWOM1] I want to share information about brands, products, or } \\
\text { services from TikTok social media with my friends }\end{array}$ & Cheung et al. (2020) \\
\hline & $\begin{array}{l}\text { [EWOM2] I want to upload content from TikTok social media on } \\
\text { my Facebook page or blog }\end{array}$ & Cheung et al. (2020) \\
\hline & $\begin{array}{l}\text { [EWOM3] I want to share opinions about brands, goods, or } \\
\text { services obtained from TikTok social media with my friends }\end{array}$ & Cheung et al. (2020) \\
\hline & $\begin{array}{l}\text { [EWOM4] The information I receive through TikTok is usually } \\
\text { trustworthy }\end{array}$ & Gvili and Levy (2018) \\
\hline \multirow[t]{4}{*}{ Brand Awareness } & [BAW1] I always know TikTok & Cheung et al. (2020) \\
\hline & [BAW2] TikTok characteristics came to my mind quickly & Cheung et al. (2020) \\
\hline & [BAW3] I can quickly remember Tiktok symbols or logos & Cheung et al. (2020) \\
\hline & [BAW4] I often remember TikTok & Cheung et al. (2020) \\
\hline \multirow[t]{4}{*}{ Brand Image } & $\begin{array}{l}\text { [BMG1] Compared to other brands, TikTok products are of high } \\
\text { quality }\end{array}$ & Cheung et al. (2020) \\
\hline & [BMG2] TikTok has a rich history & Cheung et al. (2020) \\
\hline & [BMG3] I can reliably predict how TikTok will perform & Cheung et al. (2020) \\
\hline & [BMG4] TikTok is a leading company & Cheung et al. (2020) \\
\hline \multirow[t]{4}{*}{ Brand Loyalty } & [BLY1] I would recommend the TikTok app to friends & Fernandes and Moreira (2019) \\
\hline & [BLY2] I am committed to the TikTok app & Fernandes and Moreira (2019) \\
\hline & $\begin{array}{l}\text { [BLY3] I won't buy another brand if the TikTok app is in the play } \\
\text { store or app store }\end{array}$ & Fernandes and Moreira (2019) \\
\hline & [BLY4] I am loyal to the TikTok app & Fernandes and Moreira (2019) \\
\hline \multirow[t]{4}{*}{ Cognitive CBE } & [COG1] I think a lot about TikTok content & Fernandes and Moreira (2019) \\
\hline & [COG2] TikTok interests me & Fernandes and Moreira (2019) \\
\hline & [COG3] When I use TikTok I forget everything & Fernandes and Moreira (2019) \\
\hline & [COG4] My time passed when I interacted with TikTok & Fernandes and Moreira (2019) \\
\hline \multirow[t]{4}{*}{ Affective CBE } & [AFF1] TikTok inspires me & Fernandes and Moreira (2019) \\
\hline & [AFF2] I'm proud to use the TikTok app & Fernandes and Moreira (2019) \\
\hline & [AFF3] I use the TikTok app with total dedication & Fernandes and Moreira (2019) \\
\hline & [AFF4] Using the TikTok app makes me happy & Fernandes and Moreira (2019) \\
\hline \multirow[t]{4}{*}{ Behavioral CBE } & [BEH1] I spend a lot of time using the TikTok app & Fernandes and Moreira (2019) \\
\hline & [BEH2] TikTok is one that I use a lot in social media & Fernandes and Moreira (2019) \\
\hline & [BEH3] In social media I always use the TikTok app & Fernandes and Moreira (2019) \\
\hline & [BEH4] I've always felt like using the TikTok app & Fernandes and Moreira (2019) \\
\hline
\end{tabular}

Source: Author (2021)

\section{RESULTS AND DISCUSSIONS}

The respondents criteria includes TikTok users, respondent gender, respondent age, and respondent's occupation. The majority of respondents are women aged 15-25 years with student work.

The outer model analysis provides a specification between latent variables and their manifest variables, 
or how each indicator relates to latent variables. The outer model for reflective indicators is done by looking at convergent validity, composite reliability $>$ 0,7 followed by average variance extracted (AVE) $>$ 0,5 and Cronbach's alpha value $>0,7$ for all constructs (Nasution et al., 2020). The statement can be seen in Table 2.

Table 2 Respondents' Profile

\begin{tabular}{lcc}
\hline $\begin{array}{l}\text { Demographic } \\
\text { Characteristic }\end{array}$ & Categories & Percentage \\
\hline Gender & Men & $33,6 \%$ \\
& Women & $66,4 \%$ \\
Age & $15-19$ & $41,9 \%$ \\
& $20-25$ & $47,6 \%$ \\
& $26-30$ & $5,2 \%$ \\
Job & $>30$ & $5,2 \%$ \\
& Student & $79,5 \%$ \\
& Officer/Profesional & $11,8 \%$ \\
& Enterpreneur & $6,6 \%$ \\
& Others & $0,4 \%$ \\
\hline
\end{tabular}

Source: Data Collection Results through Excel Application (2021)

It is followed by average variance extracted (AVE) $>0,5$ and Cronbach's alpha value $>0,7$ for all constructs (Nasution et al., 2020). The statement can be seen in Table 3 .

Table 3 Outer Model

\begin{tabular}{lccc}
\hline Variable & $\begin{array}{c}\text { Average } \\
\text { Variance } \\
\text { Extracted } \\
\text { (AVE) }\end{array}$ & $\begin{array}{c}\text { Cronbach's } \\
\text { Alpha (CA) }\end{array}$ & $\begin{array}{c}\text { Composite } \\
\text { Reliability } \\
\text { (CR) }\end{array}$ \\
\hline AFF & 0,818 & 0,947 & 0,925 \\
BAW & 0,855 & 0,946 & 0,915 \\
BEH & 0,857 & 0,960 & 0,942 \\
BLY & 0,832 & 0,952 & 0,932 \\
BMG & 0,766 & 0,908 & 0,847 \\
CBE & 0,780 & 0,972 & 0,968 \\
COG & 0,867 & 0,929 & 0,848 \\
CTN & 0,784 & 0,935 & 0,908 \\
ENT & 0,818 & 0,947 & 0,924 \\
EWOM & 0,780 & 0,934 & 0,906 \\
INT & 0,807 & 0,944 & 0,921 \\
TNS & 0,824 & 0,949 & 0,929 \\
\hline
\end{tabular}

Source: SmartPLS 3.0 (2021)

In the outer loading, all indicators of each variable on the model have a loading factor above 0,5 which have met the convergent validity (Hair, 2017). All AVE values in the research show a construction value greater than 0,5 , which can be seen in Table 4 .

Table 4 Outer Loading

\begin{tabular}{|c|c|c|c|c|c|c|c|c|}
\hline & BAW & BLY & BMG & CTN & ENT & EWOM & INT & TNS \\
\hline BAW1 & 0,962 & & & & & & & \\
\hline BAW2 & 0,856 & & & & & & & \\
\hline BAW4 & 0,953 & & & & & & & \\
\hline BLY1 & & 0,888 & & & & & & \\
\hline BLY2 & & 0,954 & & & & & & \\
\hline BLY3 & & 0,865 & & & & & & \\
\hline BLY4 & & 0,939 & & & & & & \\
\hline BMG1 & & & 0,903 & & & & & \\
\hline BMG2 & & & 0,851 & & & & & \\
\hline BMG3 & & & 0,871 & & & & & \\
\hline CTN1 & & & & 0,875 & & & & \\
\hline CTN2 & & & & 0,933 & & & & \\
\hline CTN3 & & & & 0,886 & & & & \\
\hline CTN4 & & & & 0,845 & & & & \\
\hline ENT1 & & & & & 0,980 & & & \\
\hline ENT2 & & & & & 0,945 & & & \\
\hline ENT3 & & & & & 0,909 & & & \\
\hline ENT4 & & & & & 0,771 & & & \\
\hline EWOM1 & & & & & & 0,911 & & \\
\hline EWOM2 & & & & & & 0,864 & & \\
\hline
\end{tabular}


Table 4 Outer Loading (Continued)

\begin{tabular}{|c|c|c|c|c|c|c|c|c|}
\hline & BAW & BLY & BMG & CTN & ENT & EWOM & INT & TNS \\
\hline EWOM3 & & & & & & 0,869 & & \\
\hline EWOM4 & & & & & & 0,887 & & \\
\hline INT1 & & & & & & & 0,927 & \\
\hline INT2 & & & & & & & 0,936 & \\
\hline INT3 & & & & & & & 0,898 & \\
\hline INT4 & & & & & & & 0,828 & \\
\hline TNS1 & & & & & & & & 0,892 \\
\hline TNS2 & & & & & & & & 0,937 \\
\hline TNS3 & & & & & & & & 0,899 \\
\hline TNS4 & & & & & & & & 0,903 \\
\hline
\end{tabular}

Source: SmartPLS 3.0 (2021)

Table 5 Fornell-larcker Criterion

\begin{tabular}{lcccccccccccc}
\hline & AFF & BAW & BEH & BLY & BMG & CBE & COG & CTN & ENT & EWOM & INT & TNS \\
\hline AFF & 0,904 & & & & & & & & & & & \\
BAW & 0,714 & 0,925 & & & & & & & & & & \\
BEH & 0,886 & 0,701 & 0,926 & & & & & & & & & \\
BLY & 0,868 & 0,669 & 0,782 & 0,912 & & & & & & & & \\
BMG & 0,858 & 0,771 & 0,818 & 0,760 & 0,875 & & & & & & & \\
CBE & 0,973 & 0,743 & 0,961 & 0,871 & 0,868 & 0,883 & & & & & & \\
COG & 0,910 & 0,729 & 0,859 & 0,888 & 0,821 & 0,944 & 0,931 & & & & & \\
CTN & 0,729 & 0,661 & 0,587 & 0,635 & 0,813 & 0,697 & 0,711 & 0,885 & & & & \\
ENT & 0,816 & 0,765 & 0,732 & 0,711 & 0,803 & 0,786 & 0,685 & 0,705 & 0,904 & & & \\
EWOM & 0,843 & 0,792 & 0,746 & 0,761 & 0,826 & 0,835 & 0,831 & 0,761 & 0,779 & 0,883 & & \\
INT & 0,778 & 0,793 & 0,790 & 0,653 & 0,832 & 0,818 & 0,791 & 0,787 & 0,767 & 0,812 & 0,898 & \\
TNS & 0,789 & 0,796 & 0,619 & 0,677 & 0,835 & 0,740 & 0,735 & 0,857 & 0,823 & 0,826 & 0,749 & 0,908 \\
\hline
\end{tabular}

Source: SmartPLS 3.0 (2021)

Table 6 Heterotrait and Monotrait Ratio (HTMT)

\begin{tabular}{lcccccccccccc}
\hline & AFF & BAW & BEH & BLY & BMG & CBE & COG & CTN & ENT & EWOM & INT & TNS \\
\hline AFF & & & & & & & & & & & & \\
BAW & 0,762 & & & & & & & & & & & \\
BEH & 0,988 & 0,735 & & & & & & & & & & \\
BLY & 0,922 & 0,824 & 0,843 & & & & & & & & & \\
BMG & 0,888 & 0,984 & 0,826 & 0,906 & & & & & & & & \\
CBE & 1,100 & 0,787 & 1,059 & 0,917 & 0,887 & & & & & & & \\
COG & 0,971 & 0,830 & 0,890 & 0,944 & 0,905 & 1,096 & & & & & & \\
CTN & 0,662 & 0,828 & 0,646 & 0,594 & 0,825 & 0,625 & 0,520 & & & & & \\
ENT & 0,747 & 0,806 & 0,684 & 0,604 & 0,755 & 0,677 & 0,550 & 1,068 & & & & \\
EWOM & 0,777 & 0,831 & 0,678 & 0,801 & 0,812 & 0,746 & 0,749 & 0,764 & 0,627 & & & \\
INT & 0,673 & 0,792 & 0,646 & 0,606 & 0,709 & 0,662 & 0,627 & 0,850 & 0,721 & 0,853 & & \\
TNS & 0,741 & 0,990 & 0,685 & 0,759 & 0,892 & 0,705 & 0,647 & 0,971 & 0,946 & 0,845 & 0,795 & \\
\hline
\end{tabular}

Source: SmartPLS 3.0 (2021) 
In the results of cross, loadings can be concluded that all indicators have a coefficient of collation greater than each construct than the value of the correlation coefficient of indicators in other column construct blocks (Hair, 2017). Therefore, it can be concluded that the discriminant validity in the research is in accordance with the criteria that have been determined (Hair, 2017). Table 5 and Table 6 provide the details of test results.

The construct reliability test is measured by the value of Cronbach's alpha and composite reliability. Next for Cronbach's alpha value, all constructs must be higher than 0,7 (Hair, 2017). In the research, the entire value of Cronbach's alpha $>0,7$ (Hair, 2017). It can be concluded that all indicators in the research have been consistent in measuring the construct (Hair, 2017).

The test of structural models or inner models by looking at the value of R-squared is a test of the goodness-fit model. The R-squared CBE value is 0,775 showing that consumer brand engagement can be explained by entertainment, interaction, trendiness, customisation, and eWOM by $77,5 \%$ while the rest is explained by other factors. The R-squared brand awareness value is 0,552 revealing that brand awareness can be explained by consumer brand engagement by $55,2 \%$ while the rest is identified by other factors. The $\mathrm{R}$-squared brand image value is 0,753 which reveals that brand image can be explained by consumer brand engagement by $75,3 \%$ while the rest is explained by other factors. Lastly, the R-squared brand loyalty value is 0,759 which shows that brand loyalty can be explained by Consumer Brand Engagement by 75,9\% while the rest is explained by other factors.

In the structural model, data analysis is conducted to look for some significant associations between exogenous variables and endogenous variables. The T-statistic value is calculated using calculate PLS Bootstrapping. All indicators with a T-statistic value $>1,96$ (rounded in half) can be said that $\mathrm{H}_{0}$ is rejected or significant, or if the value of $\mathrm{P}$-Value $<0,05$, which can be seen in Table 7 .

Table 7 Path Coefficients

\begin{tabular}{lcccccc}
\hline \multicolumn{1}{c}{ Effects } & Path Coefficients & Mean & Standard Deviation & T-statistics & P Values & Result \\
\hline CBE $=>$ BAW & 0,644 & 0,647 & 0,050 & 12,902 & 0,000 & Accepted \\
CBE $=$ = BLY & 0,796 & 0,796 & 0,030 & 26,339 & 0,000 & Accepted \\
CBE $=$ - BMG & 0,703 & 0,705 & 0,035 & 19,899 & 0,000 & Accepted \\
CTN $=>$ CBE & $-0,082$ & $-0,079$ & 0,064 & 1,286 & 0,199 & Rejected \\
ENT $=>$ CBE & 0,267 & 0,266 & 0,077 & 3,486 & 0,000 & Accepted \\
EWOM $=>$ CBE & 0,400 & 0,397 & 0,072 & 5,526 & 0,000 & Accepted \\
INT $=>$ CBE & 0,176 & 0,177 & 0,080 & 2,202 & 0,000 & Accepted \\
TNS $=>$ CBE & 0,099 & 0,101 & 0,069 & 1,447 & 0,149 & Rejected \\
\hline
\end{tabular}

Source: SmartPLS 3.0 (2021)

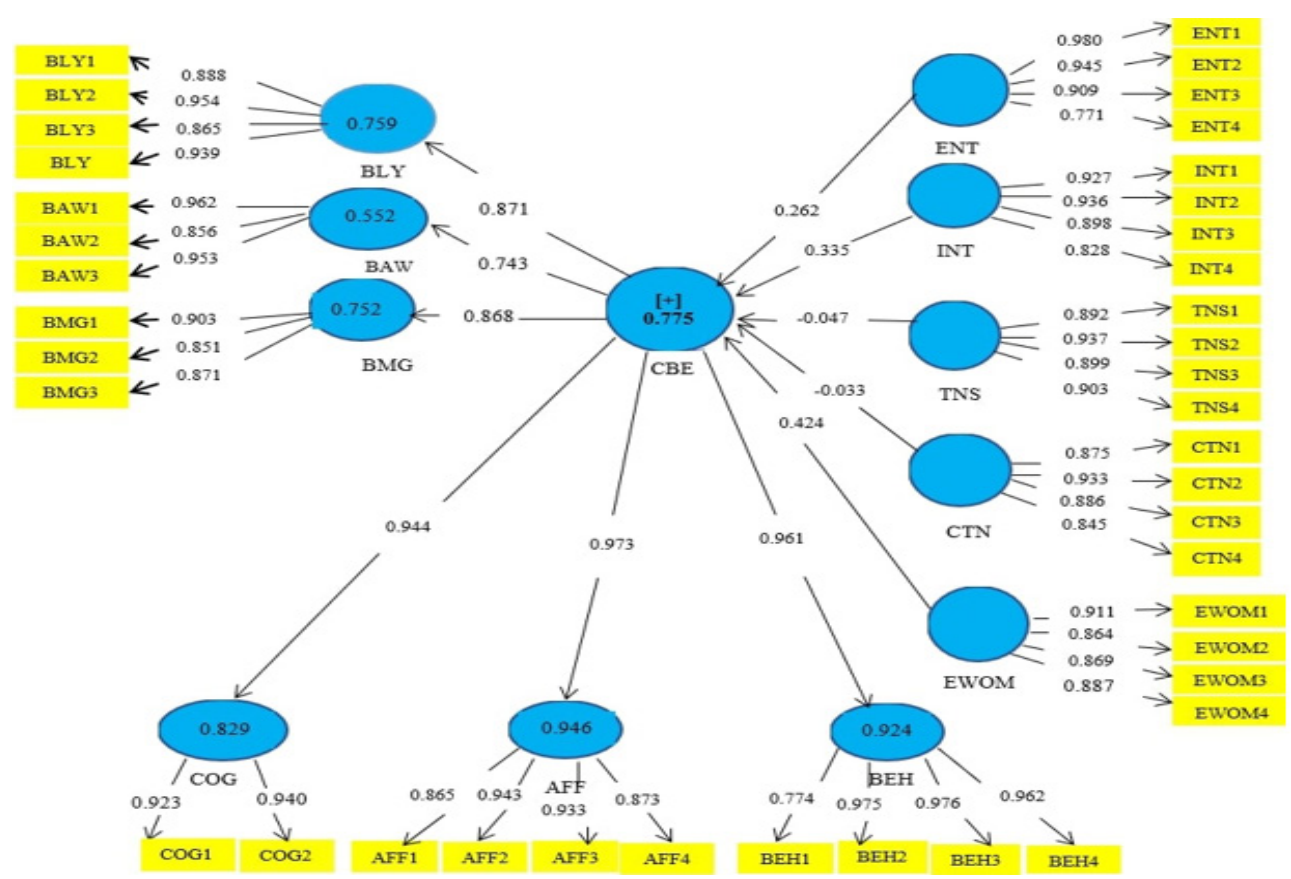

Figure 2 Outer Model

Source: Author (2021) 
Based on Table 7 and Figure 2, the result of the T-statistic value is $3,486>1,96$ so it can be concluded that there is a positive and significant influence of entertainment on consumer brand engagement. In previous research, entertainment leads to a positive consumer experience to build consumer psychology in the brand by building consumer brand engagement.

Interaction has a positive impact on consumer brand engagement. The result of the T-statistic value is $2,202>1,96$ so it can be concluded that there is a positive and significant influence of interaction towards consumer brand engagement. This is in line with the previous research that interaction is found to have positive impact by increasing customer satisfaction and being active on social media to develop further in consumer brand engagement.

Regarding trendiness towards consumer brand engagement, the result of the T-statistic value is 1,447 $<1,96$. It can be concluded that there is a negative and insignificant influence of trendiness on consumer brand engagement. Nevertheless, the result is not in line with the previous research finding that trendiness has positive influence since trendy information helps attract consumer attention, arouses positive feelings, and encourages loyalty intentions. The argument supports that trendiness can strengthen consumer emotional in contributing to strengthening consumer brand engagement.

Regarding the effect of customisation on consumer brand engagement, the result of the T-statistic value is $1,286<1,96$. It is concluded that customisation has a negative and insignificant influence on consumer brand engagement. In contrast, previous research shows that customisation has positive impact as it improves consumers' cognitive understanding of brands, as well as increases brand love that can strengthen consumer brand engagement.

Electronic word of mouth is found to have a positive and significant influence on consumer brand engagement since the result of the T-statistic value is $5,526>1,96$. The result is in line with the preceding research finding that electronic word of mouth on social media platforms and users help create a positive brand experience and beneficial emotions for the brand to strengthen consumer brand engagement.

Next, it is found that consumer brand engagement significantly and positively impacts brand loyalty since the result of the T-statistic value is 26,339 $>1,96$. The result is considered in line with earlier research identifying consumer brand engagement allows customers to grow loyalty to the brand and use the current and future brands, so it influences current and future sales constantly.

The research finds that consumer brand engagement has a positive and significant impact on brand awareness as the result of the T-statistic value is $12,902>1,96$. The finding supports previous research discovering that consumer brand engagement encourages some information related to the brand among consumers, strengthens the interaction between consumers and brands by attracting their attention, and allows consumers to keep the brand in mind.

Lastly, regarding consumer brand engagement's impact on brand image, the result of the T-statistic value is $19,899>1,96$. Thus it is believed that consumer brand engagement positively and significantly influences towards brand image. The finding supports the preceding research which states that consumer brand engagement can react in response to consumer content on social media to help consumers solve a problem. The emotional attachment to the brand is built through account-based management (ABE) by improving the brand's strong and positive attitudes.

\section{CONCLUSIONS}

Data analysis conducted using SEM PLS method comes up with several conclusions. First, entertainment, electronic word of mouth, and interaction positively affect consumer brand engagement. In developing the tourism sector, entertainment, electronic word of mouth, and interaction in TikTok application need to be improved for consumer brand engagement to increase. However, customisation and trendiness do not affect consumer brand engagement since TikTok focuses more on spreading entertaining information.

Second, consumer brand engagement is found to have positive influences towards brand awareness, brand image, and brand loyalty. In creating customer relations to develop the tourism sector in Indonesia, it is necessary to keep up the efforts to increase brand awareness, brand image, and brand loyalty.

The results show that consumer brand engagement $(\mathrm{CBE})$ is the main factor influencing brand awareness, brand image, and brand loyalty in the tourism sector in Indonesia. CBE predominantly affects brand loyalty, with a coefficient path value of 0,871. This means that CBE or good relations with tourism customers in Indonesia must be improved for brand loyalty, in this case loyalty to tourism, to increase. Furthermore, CBE also affects brand image and brand awareness. Therefore, tourism managers should pay attention to various items on the CBE's ease of expressing opinions or conversations with other users, building two-way interactions, and sharing information with other users through TikTok platform.

Meanwhile, CBE is built from the social media marketing model consisting of entertainment, interaction, trendiness, customisation, and eWOM. Electronic word of mouth is the most dominant influencing CBE with a coefficient path value of 0,424 , followed by interaction and entertainment, with coefficient path values of 0,335 and 0,262 , respectively.

It is advisable that tourism managers pay more attention to eWOM, interaction, and entertainment in building good relationships with customers. EWOM as the dominant factor influencing $\mathrm{CBE}$ can be built by providing information about the brand, opinion, products, or tourism services of TikTok shared with its users, and producing interesting and creative TikTok content so that users do not hesitate from TikTok 
social media on their Facebook page or blog.

The research has its limitation since it only focuses on TikTok users aged 20 - 25 years. Further research can focus on a wider range of objects on tourism in various regions in Indonesia such as Yogyakarta, Bandung, etc. Then further research can use other applications to be researched such as YouTube, Facebook, Twitter, etc. Similar research can be done using based on the TikTok phenomenon which is quite rapidly developing as one of the social media. In the future, the social media marketing model can be used to assess the effectiveness of SMEs' business in Indonesia by using TikTok application.

\section{REFERENCES}

Barger, V., Peltier, J. W., \& Schultz, D. E. (2016). Social media and consumer engagement: A review and research agenda. Journal of Research in Interactive Marketing, 10(4), 268-287. https://doi.org/10.1108/ JRIM-06-2016-0065.

Bilgin, Y. (2018). The effect of social media marketing activities on brand awareness, brand image and brand loyalty. Business \& Management Studies: An International Journal, 6(1), 128-148. https://doi. org/10.15295/bmij.v6i1.229.

Bresnick, E. (2019). Intensified play: Cinematic study of TikTok mobile app. University of Southern California, 4(4), 1-12.

Brodie, R. J., Ilic, A., Juric, B., \& Hollebeek, L. (2013). Consumer engagement in a virtual brand community: An exploratory analysis. Journal of Business Research, 66(1), 105-114. https://doi.org/10.1016/j. jbusres.2011.07.029.

Cahyani, K. I. \& Sutrasmawati, E. (2016). Pengaruh brand awareness dan brand image terhadap keputusan pembelian. Management Analysis Journal, 5(4), 281-288. https://doi.org/10.15294/maj.v5i4.8350.

Chahal, H. \& Rani, A. (2017). How trust moderates social media engagement and brand equity. Journal of Research in Interactive Marketing, 11(3), 312-335. https://doi.org/10.1108/JRIM-10-2016-0104.

Cheung, M. L., Pires, G., \& Rosenberger, P. J. (2020). The influence of perceived social media marketing elements on consumer-brand engagement and brand knowledge. Asia Pacific Journal of Marketing and Logistics, 32(3), 695-720. https://doi.org/10.1108/ APJML-04-2019-0262.

Dessart, L., Veloutsou, C., \& Morgan-Thomas, A. (2015). Consumer engagement in online brand communities: A social media perspective. Journal of Product and Brand Management, 24(1), 28-42. https://doi. org/10.1108/JPBM-06-2014-0635.

Dwivedi, A. (2015). A higher-order model of consumer brand engagement and its impact on loyalty intentions. Journal of Retailing and Consumer Services, 24(C), 100-109. https://doi.org/10.1016/j. jretconser.2015.02.007.

Fernandes, T. \& Moreira, M. (2019). Consumer brand engagement, satisfaction and brand loyalty:
A comparative study between functional and emotional brand relationships. Journal of Product and Brand Management, 28(2), 274-286. https://doi. org/10.1108/JPBM-08-2017-1545.

Gallaugher, J. \& Ransbotham, S. (2010). Social media and customer dialog management at Starbucks. A framework for analyzing social-media-based customer dialog. MIS Quarterly Executive, 9(4), 197-212.

Genadi, Y. D. \& Furkan, L. M. (2020). Pengaruh informativeness, entertainment, dan irritating terhadap attitude toward social media advertising pada masyarakat Kota Mataram. Jurnal Magister Manajemen, 9(2), 186. https://doi.org/10.29303/ jmm.v9i2.538.

Gvili, Y. \& Levy, S. (2018). Customer engagement with eWOM on social media: The role social capital. Online Information Review, 24(4), 482-505. https:// doi.org/10.1108/OIR-05-2017-0158.

Hair, Jr., J. F., Hult, G. T. M., Ringle, C. M. \& Sarstedt, M. (2017). A Primer on Partial Least Squares Structural Equation Modelling (PLS-SEM) (2 ${ }^{\text {nd }}$ Ed.). Los Angeles: SAGE Publications, Inc.

Janadari, M. P. N., Ramalu, S. S., \& Wei, C. C. (2018). Evaluation of measurment and structural model of the reflective model constructs in PLS-SEM. The Sixth $\left(6^{\text {th }}\right)$ International Symposium of South Eastern University of Sri Lanka, 187-194.

Kandampully, J., Zhang, T., \& Bilgihan, A. (2015). Customer loyalty: A review and future directions with a special focus on the hospitality industry. International Journal of Contemporary Hospitality Management, 27(3), 379-414. https://doi. org/10.1108/IJCHM-03-2014-0151.

Keller, K. L. (2010). Brand equity management in a multichannel, multimedia retail environment. Journal of Interactive Marketing, 24(2), 58-70. https://doi.org/10.1016/j.intmar.2010.03.001.

Khan, I., Rahman, Z., \& Fatma, M. (2016). The role of customer brand engagement and brand experience in online banking. International Journal of Bank Marketing, 34(7), 1025-1041. https:/doi. org/10.1108/IJBM-07-2015-0110.

Langaro, D., Rita, P., \& de Fátima Salgueiro, M. (2018). Do social networking sites contribute for building brands? Evaluating the impact of users' participation on brand awareness and brand attitude. Journal of Marketing Communications, 24(2), 146-168. https:// doi.org/10.1080/13527266.2015.1036100.

Liu, F., Li, J., Mizerski, D., \& Soh, H. (2012). Self-congruity, brand attitude, and brand loyalty: A study on luxury brands. European Journal of Marketing, 46(7), 922937. https://doi.org/10.1108/03090561211230098.

Liu, X., Shin, H., \& Burns, A. C. (2021). Examining the impact of luxury brand's social media marketing on customer engagement: Using big data analytics and natural language processing. Journal of Business Research, 125, 815-826. https://doi.org/10.1016/j. jbusres.2019.04.042.

Mileva, L. \& Fauzi DH, A. (2018). Pengaruh social media marketing terhadap keputusan pembelian 
(survei online pada mahasiswa sarjana jurusan Ilmu Administrasi Bisnis Angkatan 2014/2015 Fakultas Ilmu Administrasi Universitas Brawijaya yang Membeli Starbucks. Jurnal Administrasi Bisnis (JAB), 58(1), 190-199.

Nasution, M. I., Fahmi, M., Jufrizen, Muslih, \& Prayogi, M. A. (2020). The quality of small and medium enterprises performance using the Structural Equation Model-Part Least Square (SEM-PLS). Journal of Physics: Conference Series, 1477(5). https://doi.org/10.1088/1742-6596/1477/5/052052.

Patterson, P., Yu, T., \& de Ruyter, K. (2006). Understanding customer engagement in services. Proceedings of ANZMAC 2006 Conference, 1-47.

Perkembangan pariwisata Juli 2020. (2020). Badan Pusat Statistik (BPS). https://www.bps.go.id/website/ images/Pariwisata-Rilis-September-2020-ind.jpg

Putra, A. R. A. \& Mudiantono. (2014). Analisis pengaruh daya tarik pesan iklan, persepsi kemanfaatan, citra merek pada media sosial Twitter terhadap pembentukan brand awareness (Studi kasus pada media sosial Twitter@infoUNDIP atau Info Undip
Media). Diponegoro Journal of Management, 3(3), 1-12.

Rahman, I. A., Memon, A. H., \& Karim, A. T. A. (2013). Examining factors affecting budget overrun of construction projects undertaken through management procurement method using PLSSEM approach. Procedia - Social and Behavioral Sciences, 107, 120-128. https://doi.org/10.1016/j. sbspro.2013.12.407.

Seo, E-J. \& Park, J-W. (2018). A study on the effects of social media marketing activities on brand equity and customer response in the airline industry. Journal of Air Transport Management, 66(C), 36-41. https:// doi.org/10.1016/j.jairtraman.2017.09.014.

Su, Y., Baker, B. J., Doyle, J. P., \& Yan, M. (2020). Fan engagement in 15 seconds: Athletes' relationship marketing during a pandemic via TikTok. International Journal of Sport Communication, 13(3), 436-446. https://doi.org/10.1123/ijsc.20200238 .

UNWTO. (2021). UNWTO World Tourism Barometer. https://doi.org/10.18111/wtobarometereng. 